Jurnal Onoma: Pendidikan, Bahasa dan Sastra

ISSN 2443-3667 (print)

PBSI FKIP Universitas Cokroaminoto Palopo

ISSN 2715-4564 (online)

Volume 6 Nomor 2

\title{
Membangun Gerakan Literasi Sekolah melalui "Koper"
}

\author{
Nana Triana Winata \\ Prodi Pendidikan Bahasa dan Sastra Indonesia, Universitas Wiralodra \\ nana.winata@unwir.ac.id
}

\begin{abstract}
Abstrak
Gerakan literasi sekolah yang ada di Indramayu mewajibkan siswanya untuk melaksanakan kegiatan literasi 15 menit sebelum memulai pembelajaran. Dengan kegiatan tersebut, diharapkan minat baca siswa semakin tumbuh. Dengan adanya kegiatan Koper dapat terus memantau minat baca siswa di luar lingkungan sekolah, karena ketika di luar lingkungan sekolah siswa sangat sulit menemukan buku bacaan. Untuk itu, Koper memfasilitasi siswa agar tetap membaca buku di luar lingkungan sekolah. Tujuan dalam penelitian ini adalah (1) mengetahui profil minat membaca siswa; (2) mengetahui kegiatan Koper dalam upaya memotivasi membaca siswa. Penelitian kualitatif merupakan metodemetode untuk mengeksplorasi dan memahami makna yang oleh sejumlah individu atau sekelompok orang dianggap berasal dari masalah sosial atau kemanusiaan. Penelitian ini menggunakan metode kualitatif deskriptif yang melukiskan suatu keadaan objektif atau peristiwa tertentu berdasarkan faktafakta yang tampak atau sebagaimana mestinya yang kemudian diiringi dengan upaya pengambilan kesimpulan umum berdasarkan fakta-fakta historis tersebut. Selain mengetahui profil minat baca siswa yang ada di SDN 1 Drunten Wetan, Strategi yang dilaksanakan oleh Koper dalam kegiatan literasi ini adalah (a) mengenalkan kata baku melalu media; (b) membaca dongeng dan buku bacaan yang bervariatif; dan (c) khusus bagi siswa yang buta huruf, memperkenalkan huruf dengan menggunakan media.
\end{abstract}

Kata kunci: gerakan literasi sekolah, komunitas peduli literasi

\section{Pendahuluan}

Pada 2019 pemerintah memiliki slogan "SDM unggul dan Indonesia Maju”, untuk mencapai SDM (Sumber Daya Manusia) yang unggul salah satu indikator ketercapaiannya adalah melalui Gerakan Literasi Nasional (GLN) atau Gerakan Literasi Sekolah (GLS). Gerakan literasi sebenarnya sudah gencar dilaksanakan oleh Kementerian Pendidikan dan Kebudayaan (Kemdikbud) melalui Badan Pengembangan dan Pembinaan Bahasa sejak tahun 2016.

Berdasarkan catatan dari Kementerian Pendidikan dan Kebudayaan yang mendapatkan pengahargaan dari UNESCO pada 2012 tentang angka melek aksara sebesar 96,51\%. Tingkat buta aksara di Indonesia semakin menurun, semenjak pemerintah gencar melaksanakan GLN di seluruh Indonesia. Literasi harus ditanamkan sejak dini, yakni sejak anak masuk sekolah tingkat PAUD. Anak harus ditanamkan minat baca, tumbuhnya minat baca bisa didapatkan dari lingkungan keluarga atau lingkungan sekolah. Ketika anak memiliki minat baca, maka angka melek aksara dapat meningkat. Menurut Wahyuni (2009), akar permasalahan dari rendahnya kemampuan literasi masyarakat Indonesia karena model pembelajaran secara umum yang digunakan belum membuat siswa harus membaca serta sistem pembelajaran membaca yang belum tepat.

Jika berbicara minat baca pada siswa, berarti harus ada fasilitas atau sarana yang dipersiapkan terlebih dahulu. Pemprov Jawa Barat telah menyediakan salah satunya adalah perpustakaan keliling, pojok baca, dan lain-lain. Tetapi, fasilitias tersebut belum seutuhnya dinikmati oleh anak-anak yang ada di Indramayu. Sejalan dengan(Antasari, 2017) menata 
Jurnal Onoma: Pendidikan, Bahasa dan Sastra PBSI FKIP Universitas Cokroaminoto Palopo Volume 6 Nomor 2
ISSN 2443-3667 (print)

ISSN 2715-4564 (online)

sarana dan area baca, menciptakan lingkungan yang kaya teks, mendisiplinkan kegiatan membaca 15 menit sebelum pelajaran dimulai, melibatkan publik dalam gerakan literasi sekolah. Arsidi (2010) menyatakan bahwa sekolah mempunyai peranan yang sangat penting dalam pembinaan, pembiasaan dan pemberian fasilitas agar minat baca dapat tumbuh dan berkembang secara terus menerus dari waktu ke waktu dengan pemberdayaan perpustakaan. Pihak sekolah harus melengkapi sarana buku yang ada di perpustakaannya dari berbagai jenis buku yang ada. Bukan hanya buku teori yang disediakan di perpustakaan, pihak sekolah juga harus menyediakan buku yang lainnya, seperti buku tentang hobi (peternakan, perikanan, pertanian, perdagangan, dan lain-lain). Sekolah harus bisa menghasilkan siswa yang literat atau siswa yang memiliki wawasan yang luas, pemahaman yang menyatakan wawasan yang luas tersebut bersinggungan dengan kata literat yang tersurat dalam pengertian yang menyatakan bahwa GLS menyangkut pembiasaan ekosistem sekolah menjadi warga yang literat sepanjang hayat (Wiedarti, 2016).

Gerakan literasi di Kabupaten Indramayu sendiri dijalankan oleh pegiat literasi atau di sekolah masing-maing. Sekolah yang ada di Indramayu mewajibkan siswanya untuk melaksanakan kegiatan literasi 15 menit sebelum memulai pembelajaran. Dengan kegiatan tersebut, diharapkan minat baca siswa semakin tumbuh. Salah satu pegiat literasi yang ada di Kabupaten Indramayu adalah Peduli Berbagi (PB), melalui program kerja dari PB itu sendiri adalah "Koper (Komunitas Peduli Literasi)". Minat baca pada anak khususnya di Kabupaten Indramayu sangat rendah, hal tersebut karena kurangnya sarana dan bimbingan dari lingkungan keluarga atau lingkungan sekolah. Sarana yang masih kurang adalah sarana buku bacaan. Buku bacaan untuk anak masih sangat jarang dijumpai baik itu di sekolah atau di lingkungan keluarga. Sejalan dengan Laksono, dkk (2016) Buku sebagai sumber ilmu, merupakan salah satu aspek yang tidak bisa terlepas dari dunia pendidikan. Peran penting dari keluarga dalam menyediakan buku bacaan untuk anak-anaknya sangatlah penting, sehingga anak tersebut terbiasa dengan kegiatan membaca. Ketika di lingkungan keluarga itu kurang dengan bahan buku bacaan untuk anak, maka anak tersebut akan malas untuk membaca. Dengan itu, pengetahuan anak akan sangat terbatas dengan kurang membacanya anak tersebut. Dengan adanya kegiatan Koper dapat terus memantau minat baca siswa di luar lingkungan sekolah, karena ketika di luar lingkungan sekolah siswa sangat sulit menemukan buku bacaan. Untuk itu, Koper memfasilitasi siswa agar tetap membaca buku di luar lingkungan sekolah. Tujuan dalam penelitian ini adalah (1) mengetahui profil minat membaca siswa; (2) mengetahui kegiatan Koper dalam upaya memotivasi membaca siswa.

\section{Landasan Teori Literasi}

Menurut PISA (2006) literasi lebih berhubungan dengan kapasitas individu dalam memahami, menggunakan, dan merefleksikan isi teks tertulis untuk mencapai tujuan seseorang dalam mengembangkan pengetahuan dan potensinya untuk berprestasi di masyarakat. UNESCO (2008) literasi adalah kemampuan mengenal, memahami, meramal, mencipta, berkomunikasi, menghitung, dan menggunakan bahan cetak dan penulisan dengan berbagai konteks. Literasi melibatkan satu kontinum pembelajaran yang 
Jurnal Onoma: Pendidikan, Bahasa dan Sastra PBSI FKIP Universitas Cokroaminoto Palopo Volume 6 Nomor 2
ISSN 2443-3667 (print)

ISSN 2715-4564 (online)

memungkinkan seorang individu mencapai tujuannya, membangun pengetahuannya dan potensinya serta turut serta dalam pembinaan masyarakat.

Menurut Grabe \& Kaplan dan Graff (2006) yang mengartikan literasi sebagai mampu untuk membaca dan menulis, sedangkan orang yang mempu keduanya disebut literat. Hal ini sejalan dengan wahyuni (2009) masyarakat literat adalah masyarakat yang memiliki kemampuan membaca dan menulis atau melek aksara. Menurut Hartati (2017) literasi secara tradisi dimaknai sebagai kemampuan menggunakan bahasa untuk membaca, menulis, mendengar dan bertutur. Literasi bukanlah sekadar keterampilan membaca dan menulis secara mekanis. Literasi meliputi tanggapan, pemahaman, dan kegiatan kehidupan sehari-hari yang tersusun dan diaplikasikan melalui kegiatan pembelajaran yang berkelanjutan.

Berdasarkan definisi literasi menurut para ahli, dapat disimpulkan literasi adalah kemampuan menggunakan keempat keterampilan berbahasa yaitu meliputi kemampuan menyimak, berbicara, membaca, dan menulis.

\section{Gerakan Literasi Sekolah}

Gerakan Literasi Sekolah (GLS) memperkuat gerakan penumbuhan budi pekerti sebagaimana dituangkan dalam Peraturan Menteri Pendidikan dan Kebudayaan Nomor 23 Tahun 2015 Pasal 2, yang berbunyi: Penumbuhan Budi Pekerti (PBP) bertujuan untuk: (a) menjadikan sekolah sebagai taman belajar yang menyenangkan bagi siswa, guru, dan tenaga kependidikan; (b) menumbuhkembangkan kebiasaan yang baik sebagai bentuk pendidikan karakter sejak di keluarga, sekolah, dan masyarakat; (c) menjadikan pendidikan sebagai gerakan yang melibatkan pemerintah, pemerintah daerah, masyarakat, dan keluarga; dan/atau (d) menumbuhkembangkan lingkungan dan budaya belajar yang serasi antara keluarga, sekolah, dan masyarakat. Salah satu dari kegiatan tersebut adalah melaksanakan kegiatan 15 menit untuk membaca buku pelajaran atau buku nonpelajaran. Kegiatan membaca ini, dilakukan sebelum waktu pembelajaran dimulai. Salah satu tujuan dari kegiatan ini adalah untuk menumbuhkan minat baca peserta didik. Sejalan dengan Antoro (2017) Munculnya pewajiban membaca merujuk pada kondisi masyarakat Indonesia saat ini. Minat baca masyarakat Indonesia, kata Anies Baswedan (Menteri Pendidikan dan Kebudayaan), sangat rendah. Itu dapat dilihat dari perilaku masyarakat di berbagai fasilitas umum dan ruang tunggu. Di halte, terminal, stasiun, atau bandara, misalnya, orang lebih banyak memegang gawai ketimbang buku.

Menurut catatan buku saku yang berjudul "Gerakan Literasi Sekolah" dari Kemdikbud (2016) memiliki dua tujuan Gerakan Literasi Sekolah (GLS), yaitu tujuan umum dan khusus. Tujuan umum menumbuhkan budi pekerti peserta didik melalui pembudayaan ekosistem literasi sekolah yang diwujudkan dalam Gerakan Literasi Sekolah agar mereka menjadi pembelajar sepanjang hayat. Tujuan khusus Gerakan Literasi Sekolah adalah (1) menumbuhkankembangkan budaya literasi membaca dan menulis siswa di sekolah; (2) meningkatkan kapasitas warga dan lingkungan sekolah agar literat; (3) menjadikan sekolah sebagai taman belajar yang menyenangkan dan ramah anak agar warga sekolah mampu mengelola pengetahuan; dan (4) menjaga keberlanjutan pembelajaran dengan menghadirkan beragam buku bacaan dan mewadahi berbagai strategi membaca.

Prinsip-prinsip Gerakan Literasi Sekolah, menurut Kemdikbud (2016)

(1) sesuai dengan tahapan perkembangan peserta didik berdasarkan karakteristiknya;

(2) dilaksanakan secara berimbang; menggunakan berbagai ragam teks dan memperhatikan kebutuhan peserta didik;

(3) berlangsung secara terintegrasi dan holistik di semua area kurikulum;

(4) kegiatan literasi dilakukan secara berkelanjutan;

(5) melibatkan kecakapan berkomunikasi lisan; dan

(6) mempertimbangkan keberagaman.

Halaman | 586 
Jurnal Onoma: Pendidikan, Bahasa dan Sastra PBSI FKIP Universitas Cokroaminoto Palopo Volume 6 Nomor 2
ISSN 2443-3667 (print)

ISSN 2715-4564 (online)

\section{Metode Penelitian}

Menurut(Creswell, 2011), penelitian kualitatif merupakan metode-metode untuk mengeksplorasi dan memahami makna yang oleh sejumlah individu atau sekelompok orang dianggap berasal dari masalah sosial atau kemanusiaan. Menerangkan bahwa metodologi kualitatif dapat dilakukan dengan berbagai pendekatan antara lain: penelitian partisipatoris, analisis wacana, etnografi, grounded theory, studi kasus, fenomenologi, dan naratif. Penelitian ini menggunakan metode kualitatif deskriptif yang melukiskan suatu keadaan objektif atau peristiwa tertentu berdasarkan fakta-fakta yang tampak atau sebagaimana mestinya yang kemudian diiringi dengan upaya pengambilan kesimpulan umum berdasarkan fakta-fakta historis tersebut.

\section{Populasi dan Sampel}

Sugiyono (2017) mengatakan bahwa populasi adalah wilayah generalisasi yang terdiri atas: objek/subjek yang mempunyai kualitas dan karakteristik tertentu yang ditetapkan oleh peneliti untuk dipelajari dan kemudian ditarik kesimpulannya. Populasi dalam penelitian adalah anak-anak Desa Drunten Wetan, Kecamatan Gabus Wetan, Kabupaten Indramayu, Jawa Barat. Sampel dalam penelitian ini dilaksanakan di SDN 1 Drunten Wetan yang berwilayah di Kabupaten Indramayu. Subjek penelitian ini adalah siswa SDN 1 Drunten Wetan, sedangkan objek penelitian ini adalah memotret kemampuan "literasi dasar" siswa SDN 1 Drunten Wetan.

\section{Data dan Sumber Data}

Data merupakan informasi yang didapat melalui pengukuran-pengukuran untuk digunakan sebagai dasar dalam penyusunan argumentasi logis menjadi fakta. Data yang disajikan dalam bentuk kata, frasa, atau kalimat dalam mendeskripsikan kegiatan literasi di SDN 1 Drunten Wetan. Sumber data dalam penelitian ini adalah siswa SDN 1 Drunten Wetan, Kabupaten Indramayu, Jawa Barat.

\section{Teknik Pengumpulan Data} Observasi

Observasi merupakan proses untuk memperoleh data dari tangan pertama dengan mengamati orang, atau proses kerja suatu produk di tempat pada saat dilakukan penelitian (Creswell, 2012). Peneliti mengobservasi kegiatan literasi melalui Koper pada Siswa SDN 1 Drunten Wetan.

\section{Dokumentasi}

Di dalam melaksanakan teknik dokumentasi, peneliti mendapatkan dokumentasi siswa yang yang sedang melaksanakan kegiatan literasi bersama Koper.

\section{Analsis}

Setelah melaksanakn observasi dan dokumentasi, peneliti menganalisis data yang sudah didapat melaui kedua teknik tersebut dan mendeskripsikan kegiatan yang telah berlangsung.

\section{Pembahasan}

\section{Profil Minat Baca Siswa}

Hasil observasi lapangan di Kecamatan Gabus Wetan, Kabupaten Indramayu salah satu Sekolah Dasar (SD) masih ada beberapa siswa yang belum bisa membaca. Dari hasil observasi tersebut, ditentukan SDN 1 Drunten Wetan sebagai populasi terhadap minat baca 
Jurnal Onoma: Pendidikan, Bahasa dan Sastra PBSI FKIP Universitas Cokroaminoto Palopo Volume 6 Nomor 2
ISSN 2443-3667 (print)

ISSN 2715-4564 (online)

siswa, karena sebagian siswa kelas 1-3 ada yang belum bisa membaca. Hal tersebut sangatlah miris jika dibandingkan dengan sekolah-sekolah yang ada di kota besar. Minat baca siswa sangatlah rendah dikarenakan kurangnya fasilitas membaca yang ada dilingkungan tersebut. Misalnya buku bacaan yang sangat terbatas, hanya buku pelajaran sekolah saja yang ada dilingkungan tersebut. Implementasi Gerakan Literasi Sekolah (GLS) di SDN 1 Drunten Wetan selalu dilaksanakan oleh pihak sekolah. Namun, pelaksanaan tersebut kurang efektif, hanya berjalan efektif beberapa bulan saja, karena sarana atau buku bacaan yang disediakan oleh pihak sekolah sangatlah terbatas sehingga siswa mulai merasa bosan dalam melaksanakan kegiatan membaca. Kurangnya fasilitas membaca untuk anak-anak menjadi pekerjaan rumah sendiri untuk guru, pihak sekolah, dan pemerintah setempat, sehingga waktu luang siswa terbuang hanya untuk bermain saja.

Dengan adanya program dari pemerintah yaitu Gerakan Literasi Sekolah (GLS) yang mengharuskan siswa meluangkan waktu 15 menit untuk membaca sebelum kegiatan pembelajaran dimulai. Kegiatan tersebut tidak efektif bagi siswa SDN 1 Drunten Wetan, karena buku bacaan yang sangat sedikit dan tidak sesuai dengan keinginan siswa tersebut. Seharusnya sebelum mengadakan GLS yang mewajibkan siswa membaca 15 menit sebelum kegaiatan pembelajaran, pihak terkait harus merombak fasilitas kegiatan GLS tersebut. Misalnya dari sarana tempat membaca yang harus membuat nyaman siswa ketika sedang membaca. Selain itu, kelengkapan buku harus bervariatif, dalam arti jenis-jenis buku harus lebih banyak lagi. Salah satu tujuan dari pemerintah dalam pelaksanaan GLS yaitu untuk menumbuhkan minat baca dari siswa tersebut. Namun, lain hal dengan yang terjadi di lapangan, karena materi bacaan yang ada tidak sesuai dengan arahan yang diinginkan oleh pemerintah yaitu materi bacaan berisi nilai-nilai budi pekerti, berupa kearifan lokal, nasional, dan global. Buku-buku bacaan yang ada di sekolah tersebut sangatlah terbatas, sehingga membuat siswa lebih malas untuk membaca buku.

Pada siswa kelas 1, sebagian besar ada yang baru belajar membaca dan ada pula yang sudah bisa membaca. Hal seperti ini menjadi tantangan tersendiri bagi guru kelas 1 tersebut. Dalam kegiatan literasi semua pihak harus ikut serta atau terlibat langsung, karena tidak bisa kegiatan tersebut dibebankan ke sekolah. Baik itu pihak keluarga yang harus memantau anaknya dalam kegiatan membaca di rumah dan pihak sekolah yang memantau siswanya dalam kegiatan membaca di sekolah. Dengan adanya kolaborasi tersebut, maka diharapkan tumbuhnya minat baca siswa. Minat baca merupakan cerminan dari tingkat kemajuan suatu bangsa atau daerah tersebut. Minat baca siswa di Kabupaten Indramayu masih tergolong rendah, karena masih ada beberapa siswa yang bekerja sebagai Anak Buah Kapal (ABK) dan Tenaja Kerja Indonesia (TKI). Selain dilihat dari mata pencarian, kurangnya minat baca siswa pun dilihat dari beberapa sekolah dasar yang ada di pinggiran Indramayu masih ada beberapa siswa yang belum bisa membaca. Kurangnya minat baca siswa dapat dilihat dari buku yang tersedia di setiap sekolah. Ada berapa jenis buku bacaan yang disiapkan oleh pihak sekolah dalam menjalankan program dari pemerintah tentang GLS. Jika jenis buku bacaan yang disiapkan sedikit atau sangat terbatas, gairah siswa untuk membaca pun tidak akan muncul. Terlebih lagi jika buku tersebut hanya berkutik seputar materi atau pelajaran saja. Membaca adalah salah satu fondasi dasar dalam keterampilan bahasa Indonesia. Dengan keterampilan membaca, dapat meningkatkan kemampuan anak untuk memahami berbagai konsep dengan mudah. Selain itu, jika dilihat lebih luas lagi kemampuan membaca dapat mengembangkan keterampilan 
Jurnal Onoma: Pendidikan, Bahasa dan Sastra PBSI FKIP Universitas Cokroaminoto Palopo Volume 6 Nomor 2
ISSN 2443-3667 (print)

ISSN 2715-4564 (online)

berpikir kritis pada siswa. Ketika siswa memperbanyak kegiatan membacanya, maka siswa tersebut secara langsung akan menambah wawasan kosakata dan dapat melatih kemampuan berkomunikasi siswa tersebut.

\section{Kegiatan Koper}

Koper merupakan akronim dari Komunitas Peduli Literasi, komunitas ini beranggotakan mahasiswa Prodi Pendidikan Bahasa dan Sastra Indonesia, Universitas Wiralodra. Koper bergerak dalam bidang literasi khususnya pada lingkungan Sekolah Dasar (SD), karena masih banyak siswa sekolah dasar yang masih belum bisa membaca. Hal tersebut membuat kami tergerak untuk turun ke lapangan langsung membantu kegiatan literasi. Koper telah melaksanakan kegiatan literasi ini, sudah hampir 20 sekolah yang ada di berbagai daerah di Kabupaten Indramayu. Salah satunya adalah SDN 1 Drunten Wetan yang berada di Kecamatan Gabus Wetan, Kabupaten Indramayu. Dari hasil observasi yang telah dilaksanakan oleh Koper mendapatkan hasil ada beberapa siswa kelas 1-3 yang belum bisa membaca. Bahkan adapula siswa kelas 5 yang belum bisa membaca sejumlah 3 orang, dan siswa kelas 6 yang belum bisa membaca sejumlah 2 orang. Hal ini membuat miris sekali, karena untuk siswa kelas 5 dan 6 masih ada yang belum bisa membaca. Padahal siswa kelas 6 yang sebentar lagi akan melanjutkan sekolah ke jenjang berikutnya, hal ini akan menjadi hambatan bagi siswa tersebut, guru, dan sekolah. Fenomena seperti itu sudah bukan hal yang terasa asing di daerah ini, karena kesadaran masyarakat untuk bersekolah sangatlah rendah. Koper peduli dengan hal ini dan melaksanakan kegiatan satu bulan di sekolah tersebut dengan pertemuan satu minggu dua kali, yaitu pada Jumat dan Sabtu.
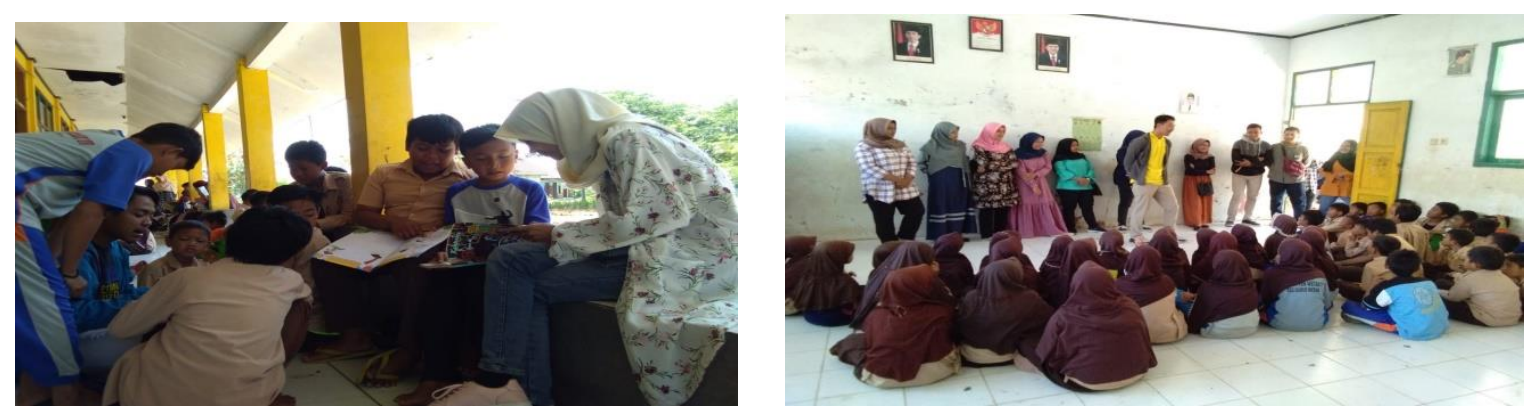

Gambar: Kegiatan Koper dan Siswa SDN 1 Drunten Wetan

Kegiatan yang dilakukan oleh Koper yaitu bermain sembari belajar membaca, kegiatan bermain agar siswa tidak merasa bosan seperti kegiatan pembelajaran di kelas. Kegiatan ini, dilakukan di luar kelas. Strategi yang dilaksanakan oleh Koper dalam kegiatan literasi ini adalah (a) mengenalkan kata baku melalu media; (b) membaca dongeng dan buku bacaan yang bervariatif; dan (c) khusus bagi siswa yang buta huruf, memperkenalkan huruf dengan menggunakan media.

(a) Mengenalkan kata baku melalui media. Pada kegiatan ini, Koper telah mempersiapkan beberapa media yang berbeda-beda dalam pelaksanaan kegiatan literasi ini, hal tersebut untuk menghindari tingkat kejenuhan siswa dalam melaksanakan kegiatan literasi bersama Koper. Salah satunya adalah dengan menggunakan "kalender kata", media tersebut seperti layaknya sebuah kalender, tetapi berisikan kata baku dan tidak baku. Pada kegiatan ini, Koper memberikan materi tentang kata kabu dan tidak baku, 
siswa secara bergiliran menjawab kata baku atau tidak baku yang ada di kalender tersebut. Kegiatan ini, selalu diulang selama satu bulan dengan kata yang selalu ganti agar wawasan kosakata siswa bertambah.
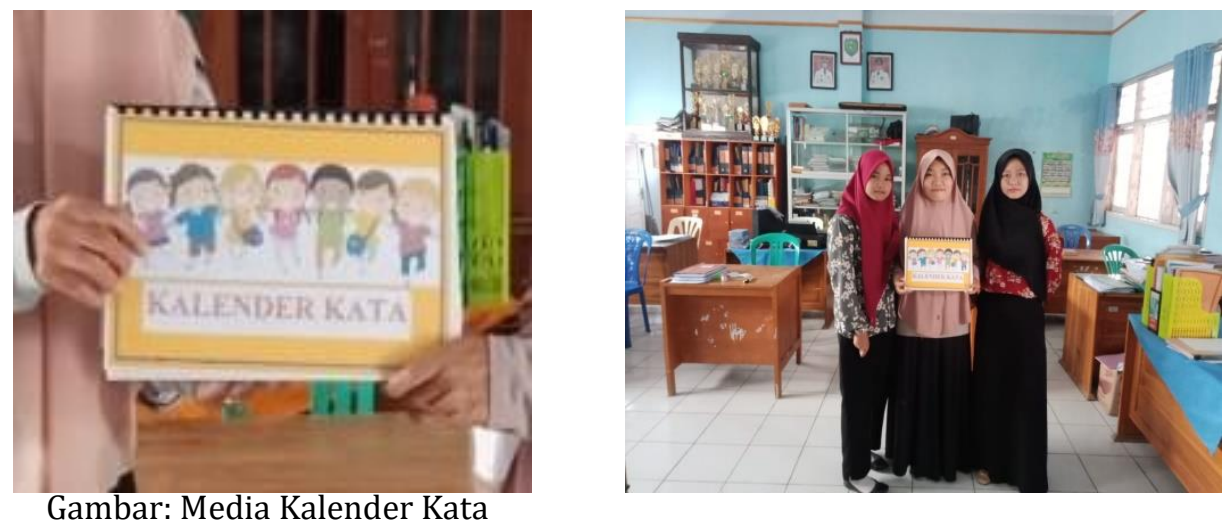

(b) Membaca dongeng \& Buku Bacaan yang bervariatif. Minat baca siswa yang rendah salah satunya adalah kurangnya koleksi buku yang dimiliki oleh sekolah. Pada kegiatan ini, Koper telah mempersiapkan 170 buku bacaan dari berbagai jenis buku bacaan diantaranya buku cerita, buku pelajaran, buku tentang hobi, buku pertanian, dan buku peternakan. Pada kegiatan ini tidak disangka siswa sangat antusias, siswa menunggu kegiatan yang ini, karena banyak jenis buku yang dibawa oleh Koper. Siswa dapat membaca sesuai dengan karakter atau hobi dari siswa tersebut. Misalnya, ada siswa yang sangat suka dengan hewan, maka siswa tersebut selalu ingin membaca buku yang berkaitan dengan hewan. Hanya saja buku yang berjenis pelajaran adalah buku yang tidak banyak dibaca oleh siswa. Siswa lebih memilih buku bacaan di luar mata pelajaran yang diajarkan di sekolah. Selain itu, dalam kegiatan membaca ini, siswa pun membaca dongeng dengan lantang di depan teman-temannya. Banyak siswa yang belum paham membaca dengan baik dan benar. Beberapa siswa masih belum paham akan kegunaan dari tanda baca yang ada, misalnya tanda baca koma (,) kegunaannya adalah memberi jeda ketika membaca teks tersebut. Akan tetapi, hampir seluruh siswa tidak ada yang memberi jeda ketika ada tanda koma (,) bahkan ketika tidak ada tanda baca tersebut, siswa membuat jeda dengan sendirinya. Hal inilah Koper memberikan edukasi cara membaca yang baik dan benar. Secara bergantian siswa membacakan sebuah cerita dongeng dari buku yang mereka baca. Kegiatan ini adalah salah satu implementasi koper dalam menutupi kekurangan sarana buku bacaan yang dimiliki oleh sekolah. Siswa dapat dengan bebas memilih buku mana yang akan dibaca.
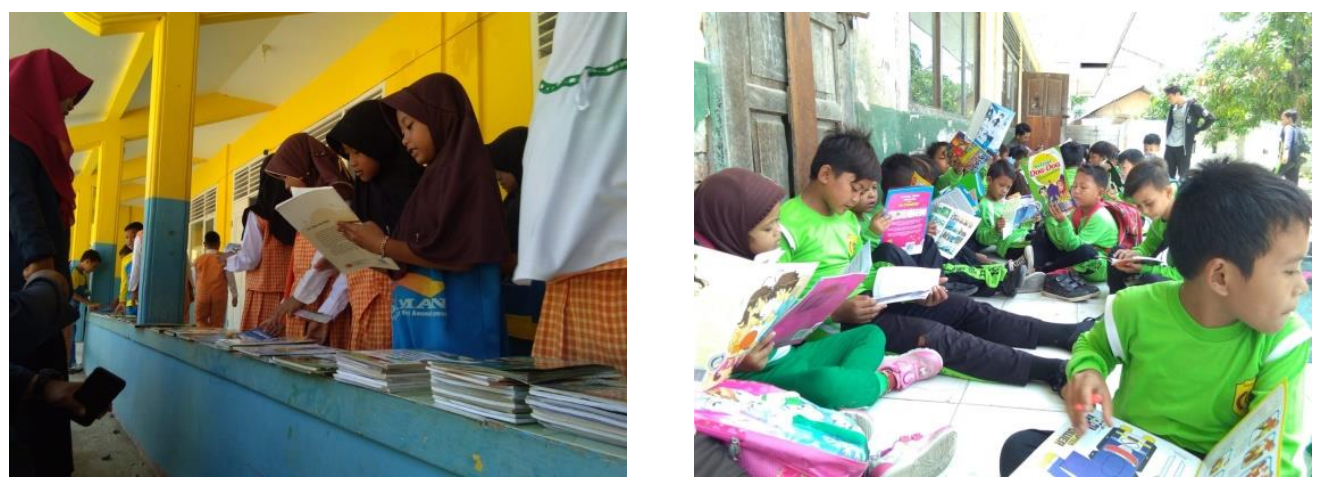

Halaman | 590 
Jurnal Onoma: Pendidikan, Bahasa dan Sastra PBSI FKIP Universitas Cokroaminoto Palopo Volume 6 Nomor 2
ISSN 2443-3667 (print)

ISSN 2715-4564 (online)

Gambar: Koleksi Buku Bacaan dari Koper

(c) Memperkenalkan huruf, pada kegiatan ini, khusus bagi siswa yang belum bisa membaca baik itu siswa kelas 1 sampai dengan siswa kelas 6, karena di sekolah tersebut masih ada beberapa siswa kelas 5 dan 6 yang belum bisa membaca. Pada kegiatan ini Koper memberikan sebuah permainan agar siswa tersebut mampu menghafalkan huruf alfabet dengan mudah dan siswa dapat dengan mudah membaca rangkaian dari hurf per huruf. Selain itu, siswa tersebut diberikan sebuah materi calistung (Baca Tulis, dan Hitung), karena materi tersebut adalah materi dasar yang harus dikuasai anak sejak dini. Kegiatan-kegiatan tersebut dilaksanakan oleh Koper selama satu bulan, selama kegiatan tersebut banyak terjadi perubahan pada siswa tersebut. Misalnya siswa yang tidak memiliki percaya diri untuk membacakan cerita di depan kelas, kini siswa tersebut memiliki kepercayaan diri untuk membacakan cerita di depan kelas. Tidak lupa fokus Koper terhadap siswa yang belum bisa membaca, agar siswa tersebut menjadi melek aksara melalui kegiatan yang dilakukan oleh Koper selama di sekolah tersebut.

\section{Simpulan}

Perlu adanya kolaborasi antara pihak sekolah, keluarga, dan pegiat literasi dalam menjalankan program dari pemerintah. Tanpa adanya sebuah kolaborasi tersebut, ketika program tersebut hanya dibebankan kepada sekolah, maka kegiatan tersebut akan sulit berjalan dengan lancar. Akan tetapi, jika adanya kolaborasi dari beberapa pihak tersebut, maka program tersebut dapat berjalan dengan lancar. Dengan adanya pegiat literasi seperti Koper dapat membantu melancarkan program dari pemerintah tentang Gerakan Literasi Nasional (GLN) dan Gerakan Literasi Sekolah (GLS). Kehadiran pegiat Koper sangat terasa dikalangan siswa yang pernah disambangi oleh Koper khususnya SDN 1 Drunten Wetan yang telah mengalami banyak perubahan pada siswanya khususnya minat dalam membaca. Diharapkan akan banyak muncul pegiat literasi khususnya di daerah Indramayu guna mempercepat menaikkan minat baca siswa. 
Jurnal Onoma: Pendidikan, Bahasa dan Sastra PBSI FKIP Universitas Cokroaminoto Palopo Volume 6 Nomor 2
ISSN 2443-3667 (print)

ISSN 2715-4564 (online)

\section{Daftar Pustaka}

Antasari, I. W. (2017). "Implementasi Gerakan Literasi Sekolah Tahap Pembiasaan di MI Muhammadiyah Gandatapa Sumbang Banyumas". Jurnal Libria IAIN Purwokerto, 9(1), 13-26.

Antoro, B. (2017). "Gerakan Literasi Sekolah dari Pucuk Hingga Akar Sebuah Refleksi". Jakarta: Direktorat Jenderal Pendidikan Dasar dan Menengah Kementerian Pendidikan dan Kebudayaan. Apandi

Arsidi. (t.t). (2010). "Pemberdayaan Perpustakaan sebagai Solusi dalam Melejitkan Prestasi". [Online]. Diakses dari: http://ejournal.usd.ac.id/index.php/Info_Pers adha/article/download/32/28 pada 10- 03-2020.

Creswell, J. W. (2011). "Research design: pendekatan kualitatif, kuantitatif, dan mixed". Yogjakarta: PT Pustaka Pelajar.

Grabe, W. \& Kaplan R. (Eds.) 1992. "Introduction to Applied Linguistics". New York: Addison-Wesley Publishing Company.

Graff, H. (2006). "Literacy". Microsoft ${ }^{\circledR E n c a r t a}{ }^{\circledR}$ [DVD]. Redmond, WA: MiscrosoftCorporation 2005.

Hartati, T. (2017). "Multimedia in Literacy Development At Remote Elementary Schools in West Java (Multimedia Dalam Pengembangan Literasi Di Sekolah Dasar Terpencil Jawa Barat)". Edutech, 15(3), 301-310.

Kemdikbud. (2015). "Permendikbud Nomor 23 Tahun 2015 tentang Penumbuhan Budi Pekerti". Jakarta: Kementerian Pendidikan dan Kebudayaan.

Kemdikbud. (2016). "Buku Saku Gerakan Literasi Sekolah". Jakarta: Direktorat Jenderal Pendidikan Dasar dan Menengah Kementerian Pendidikan dan Kebudayaan.

Laksono, K., dkk. (2016). "Manual Pendukung Pelaksanaan Gerakan Literasi Sekolah untuk Jenjang Sekolah Menengah Pertama". Jakarta: Kementerian Pendidikan dan Kebudayaan. Diakses dari https://reporsitori.perpustakaan.kemdikbud.go.id/358/1/Manual-

PendukungPelaksanaan-Gerakan-Literasi-Sekolah.pdf pada 29 April 2020.

Pratiwi, Retnaningdyah, dkk. (2016). "Panduan Gerakan Literasi di Sekolah Menengah Pertama". Jakarta: Direktorat Jenderal Pendidikan Dasar dan Menengah Kementerian Pendidikan dan Kebudayaan.

Programme for International Student Assessment, \& Source OECD (Online service). (2006). "Assessing scientific, reading and mathematical literacy: A framework for PISA 2006". Publications de l'OCDE.

Sugiyono. (2017). "Metode Penelitian \& Pengembangan: Research and Development". Bandung: Alfabeta.

Wahyuni, S. (2009). "Menumbuhkembangkan Minat Baca Menuuju Masyarakat Literat". Diksi, 16(2).

Wiedarti, P. dkk. (2016). "Desain Induk Gerakan Literasi Sekolah". Jakarta: Direktorat Jenderal Pendidikan Dasar dan Menengah Kementerian Pendidikan dan Kebudayaan. 